\title{
Elasmobranchs observed in deepwaters (45-330m) at Isla del Coco National Park, Costa Rica (Eastern Tropical Pacific)
}

\author{
Jorge Cortés ${ }^{1,2}$, Astrid Sánchez-Jiménez ${ }^{1,3}$, J. Alexander Rodríguez-Arrieta ${ }^{1,4}$, Geovanna \\ Quirós-Barrantes ${ }^{1,2}$, Paula C. González ${ }^{1} \&$ Shmulik Blum ${ }^{5}$ \\ 1. Centro de Investigación en Ciencias del Mar y Limnología (CIMAR), Ciudad de la Investigación, Universidad de \\ Costa Rica, San Pedro, 11501-2060 San José, Costa Rica; jorge.cortes@ucr.ac.cr \\ 2. Escuela de Biología, Universidad de Costa Rica, San Pedro, 11501-2060 San José, Costa Rica \\ 3. Posgrado en Gestión Integrada de Áreas Costeras Tropicales (GIACT), Sistema de Estudios de Posgrado, Universidad \\ de Costa Rica, San Pedro, 11501-2060 San José, Costa Rica; astrid_saji@hotmail.com \\ 4. Centro de Investigación en Estructuras Microscópicas (CIEMic), Ciudad de la Investigación, Universidad de Costa \\ Rica, San Pedro, 11501-2060 San José, Costa Rica \\ 5. DeepSee, UnderSea Hunter Group, San José, Costa Rica; shmulikbl@underseahunter.com
}

Received 19-V-2012. Corrected 26-VIII-2012. Accepted 24-IX-2012.

\begin{abstract}
Isla del Coco is an oceanic island 500km off the Pacific coast of Costa Rica. It is a National Park and its marine fauna has been relatively well protected. The island is famous for its elasmobranch (sharks, rays and skates) sightings in shallow waters. Here we present a catalogue of the deepwater elasmobranchs observed with the DeepSee submersible. Five species of sharks, six species of skates and one ray have been observed between 45 and 330m depth. Triaenodon obesus, the white tip reef shark, was commonly observed between 80 and $301 \mathrm{~m}$, but only in the afternoons. Sphyrna lewini, the scalloped hammerhead shark, was observed as deep a $303 \mathrm{~m}$, but commonly between 45 and $90 \mathrm{~m}$, and close to the island. Odontaspis ferox, the smalltooth sand tiger shark, was observed between 82 and $316 \mathrm{~m}$. Echinorhinus cookei, the prickly shark, was observed between 91 and $320 \mathrm{~m}$. Rhincodon typus, the whale shark, was observed only close to the island, between 77 and $80 \mathrm{~m}$. Taeniura meyeni, the marbled ray, was observed only close to the island, between 45 and $90 \mathrm{~m}$. A Dasyatis sp., similar to the the diamond stingray, was observed only once close to the island at $60 \mathrm{~m}$; this is the first report of this genus at Isla del Coco National Park. Manta birostris, the giant manta, was only observed close to the island at $90 \mathrm{~m}$. Mobula tarapacana, the sicklefin devil ray, was observed between 60 and 326m, extending its maximum depth almost 10 times what has been reported. Aetobatus narinari, the spotted eagle ray, was observed only close to the island between 60 and $82 \mathrm{~m}$. Torpedo peruana, the Peruvian torpedo ray, was observed only once at $313 \mathrm{~m}$, and is the first record of this species from Isla del Coco National Park. Citation: Cortés, J., A. Sánchez-Jiménez, J.A. Rodríguez-Arrieta, G. Quirós-Barrantes, P.C. González \& S. Blum. 2012. Elasmobranchs observed in deepwaters (45-330m) at Isla del Coco National Park, Costa Rica (Eastern Tropical Pacific). Rev. Biol. Trop. 60 (Suppl. 3): 257-273. Epub 2012 Dec 01.
\end{abstract}

Key words: Deepwater sharks and rays, Cocos Island, Costa Rica, Isla del Coco, marine biodiversity, submersible research.

Isla del Coco (also known as Cocos Island) is the only point above sea-level of the Coco Volcanic Cordillera that originates in the Galápagos Hotspot in the Eastern Tropical Pacific (Alvarado 2009, Rojas \& Alvarado 2012). It is part of the Isla del Coco National Park and located more than $500 \mathrm{~km}$ from mainland Costa Rica (Cortés 2008). The $24 \mathrm{~km}^{2}$ island is surrounded by an insular platform that deepens to around $180 \mathrm{~m}$, with an area of about $300 \mathrm{~km}^{2}$, then drops to several thousand meters deep (Lizano 2001, 2012). This submerged platform consists of rocky outcrops and sandy bottoms (Cortés \& Blum 2008).

The island has been explored down to $450 \mathrm{~m}$ with the DeepSee submersible since 
2006. Below 50m deep (the average depth of the thermocline) the environments and organisms are different than at surface (Cortés \& Blum 2008). In this paper we present the sharks, skates and rays that have been photographed between 45 and $330 \mathrm{~m}$ deep around Isla del Coco National Park. Images and species description and distribution (spatial and temporal) are presented.

\section{MATERIAL AND METHODS}

Videos are taken with a high-definition digital camera mounted on the DeepSee submersible (Cortés \& Blum 2008), at several localities around Isla del Coco National Park (Fig. 1). Videos were recorded on mini-DV tapes and then digitized to a .mov format. Image grabs of organisms, substrates and objects on the bottom were made in the laboratory using Imovie and FinalCut software. A total of 811 dives have been made, and 130 hours of the video have been recorded from 2006 to 2012. For this project 570 dives have been processed; of those, sharks, skates or rays were recorded and 397 video grabs were obtained from 87 dives. Several species were observed in only one dive, e.g. Torpedo peruana and a Dasyatis sp., while others were observed in numerous dives, such as Mobula tarpacana in 36 dives. The following was recorded for each image: dive number, dive site, date, time of day, and depth.

The fishes were identified using the following publications: Bussing and López (2005), Garrison (2005), Cortés and Blum (2008), Robertson and Allen (2008), McCosker and Rosenblatt 2010, and Long et al. (2011). The identifications together with all or some of the images were sent for corroboration to: Ginger Garrison, John E. McCosker, D. Ross Robertson, Eva Salas and Richard M. Starr. For previous reports of the species at Isla del Coco National Park, we used Bussing and López (2005, 2009), Garrison (2005), and SibajaCordero (2008).

\section{RESULTS AND DISCUSSION}

Five species of sharks and seven of rays have been observed in deepwaters at Isla del Coco National Park (Table 1). Images of the species are included together with a brief description of the species, its distribution, observations at Isla del Coco National Park (location, depth, date, time of day), previous reports of the species at Isla del Coco National Park, and comments (Figs. 2-23 (See Appendix)). Two species are reported for the first time: Dasyatis sp. and Torpedo peruana. Other species were commonly seen. Several species

TABLE 1

List of sharks and rays observed from the DeepSee at Isla del Coco National Park, Costa Rica. With common names and IUCN Red List status (IUCN 2012): EN = Endangered, VU = Vulnerable, NT = Near Threatened, DD = Data Deficient

\begin{tabular}{llll}
\multicolumn{1}{c}{ Order, Family } & \multicolumn{1}{c}{ Class Elasmobranchii } & \multicolumn{1}{c}{ Common name } & \multicolumn{1}{c}{ IUCN Status } \\
Carcharhiniformes, Carcharhinidae & Triaenodon obesus (Rüppell, 1837) & White tip reef shark & NT \\
Carcharhiniformes, Sphyrnidae & Sphyrna lewini (Griffith \& Smith, 1834) & Scalloped hammerhead shark & EN \\
Lamniformes, Odontaspididae & Odontaspis ferox (Risso, 1810) & Smalltooth sand tiger shark & VU \\
Squaliformes, Echinorhinidae & Echinorhinus cookei Pietschmann, 1928 & Prickly shark & NT \\
Orectolobiformes, Rhincodontidae & Rhincodon typus Smith, 1828 & Whale shark & VU \\
Rajiformes, Dasyatidae & Taeniura meyeni Müller \& Henle, 1841 & Marbled ray & VU \\
Rajiformes, Dasyatidae & Dasyatis sp. & Fintail stingray & DD \\
Rajiformes, Mobulidae & Manta birostris (Walbaum, 1792) & Giant manta & VU \\
Rajiformes, Mobulidae & Mobula tarapacana (Philippi, 1892) & Sicklefin devil ray & DD \\
Rajiformes, Myliobatidae & Aetobatus narinari (Euphrasen, 1790) & Spotted eagle ray & NT \\
Torpediniformes, Torpedinidae & Torpedo peruana Chirichigno, 1963 & Peruvian torpedo ray & DD \\
\hline
\end{tabular}




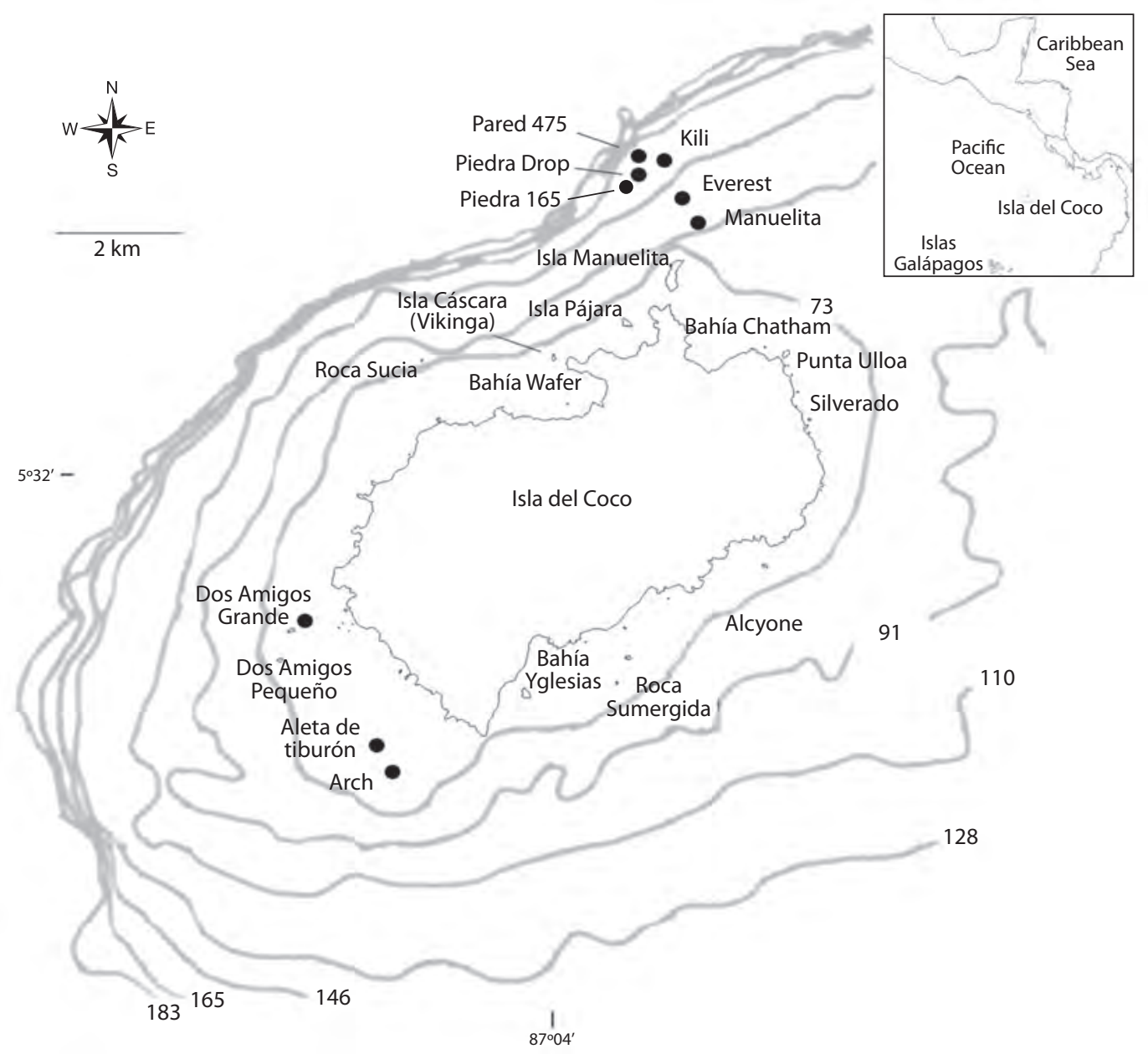

Fig. 1. Location of sites at Isla del Coco National Park where the submersible DeepSee has acquired videos of elasmobranchs since 2006.

were observed only close to the island and at the shallowest depths: Rhincodon typus, Taeniura meyeni, Dasyatis sp., Manta birostris, and Aetobatus narinari. The maximum depth range of two species is extended, Mobula tarapacana almost 10 times, to $326 \mathrm{~m}$, and Torpedo peruana more than twice, to $313 \mathrm{~m}$, what has been reported.

Garrison (2005) reports 11 species of sharks and rays for Isla del Coco National Park, while Bussing and López (2009) report 16 spp. Two other species, Echinorhinus cookei and Carcharhinus melanopterus, have recently been reported, the first by Long et al. (2011) and the second by López-Garro et al. (2012). With the species reported here, the number of sharks and rays from Isla del Coco National Park increased to 20 species. Starr et al. (2012) observed Carcharhinus falciformis in deepwaters at PNIC but we did not see it in this study.

\section{ACKNOWLEDGMENTS}

We thank the Undersea Hunter Group for the use of the images, ACMIC and the Isla del Coco National Park for extending the permits 
to develop this project. The Vicerrectoría de Investigación and the Centro de Investigación en Ciencias del Mar (CIMAR), Universidad de Costa Rica, for their financial and logistic support. The Consejo Nacional de Rectores de las Universidades Públicas (CONARE) for its financial support. We appreciate very much the time taken by the following ichthyologists to help us with the identification of the elasmobranchs and/or the review of this paper: Peter J. Auster, Felipe Galván-Magaña, Ginger Garrison, John E. McCosker and D. Ross Robertson. JC thanks Nicholas Polunin and Newcastle University, Newcastle, United Kingdom, for the oportunity to spend time there as Visiting Professor.

\section{RESUMEN}

La Isla del Coco es una isla oceánica a $500 \mathrm{~km}$ de la costa Pacífica de Costa Rica. Es un Parque Nacional donde la fauna marina ha estado relativamente bien protegida. La isla es famosa por los elasmobranquios (tiburones y rayas) en aguas poco profundas. Aquí presentamos un catálogo de elasmobranquios observados con el sumergible DeepSee. Cinco especies de tiburones y siete especies de rayas han sido observadas entre 45 y $330 \mathrm{~m}$ de profundidad. Triaenodon obesus, tiburón punta blanca de arrecifes o tiburón cazón coralero, observado comúnmente entre 80 y 301m pero solo en las tardes. Sphyrna lewini, el tiburón martillo o cornuda común, registrado hasta $303 \mathrm{~m}$, pero comúnmente entre 45 y 90m, y cerca de la Isla del Coco. Odontaspis ferox, tiburón solrayo, visto entre 82 y $316 \mathrm{~m}$. Echinorhinus cookei, tiburón negro espinoso, avistado entre 91 y $320 \mathrm{~m}$. Rhincodon typus, tiburón ballena, observado solamente cerca de la isla, entre 77 y $80 \mathrm{~m}$. Taeniura meyeni, raya moteada, vista solamente cerca de la isla, entre 45 y $90 \mathrm{~m}$. Dasyatis sp., parecida a la raya látigo, registrada solamente una vez, cerca de la isla a $60 \mathrm{~m}$; este es el primer informe de esta especie en el Parque Nacional Isla del Coco. Manta birostris, manta gigante, observada únicamente cerca de la isla a $90 \mathrm{~m}$. Mobula tarapacana, manta cornuda o manta moruma, vista entre 60 y 326m, extendiendo su profundidad máxima casi 10 veces a lo informado en la literatura. Aetobatus narinari, chucho pintado o raya águila, observada solamente cerca de la isla entre 60 y $82 \mathrm{~m}$. Por último, Torpedo peruana, raya torpedo eléctrico o raya peruana, solamente vista una vez a $313 \mathrm{~m}$ y es el primer informe de esta especie en el Parque Nacional Isla del Coco.

Palabras clave: Tiburones y rayas de profundidad, Costa Rica, Isla del Coco, biodiversidad marina, investigación con sumergible

\section{REFERENCES}

Angulo, J. \& A. Acero. 1999. Primer registro de Torpedo peruana Chirichigno (Elasmobranchii: Torpedinidae) para el Pacífico colombiano. Bol. Inv. Mar. Cost. 28: 185-190.

Alvarado, G.E. 2009. Los volcanes de Costa Rica: Geología, historia, riqueza natural y su gente, 3rd ed. Edit. UNED, San José, Costa Rica. 335 p.

Bessudo, S., G.A. Soler, P.A. Klimley, J. Ketchum, R. Arauz \& A. Hearn. 2011a. Residency of the scalloped hammerhead shark (Sphyrna lewini) at Malpelo Island and evidence of migration to other islands in the Eastern Tropical Pacific. Environ. Biol. Fish. 91: 165-176.

Bessudo, S., G.A. Soler, P.A. Klimley, J. Ketchum, R. Arauz, A. Hearn, A. Guzmán \& B. Calmettes. 2011b. Vertical and horizontal movements of the scalloped hammerhead shark (Sphyrna lewini) around Malpelo and Cocos Islands (Tropical Eastern Pacific) using satellite telemetry. Bol. Invest. Mar. Cost. 40 (Supl. Esp.): 91-106

Bessudo-Lion, S. \& S. Caballero-Gaitán. 2003. Primeras observaciones en su medio natural del tiburón Odontaspis ferox (Familia Odontaspidae) y confirmación taxonómica por métodos de identificación molecular en el Santuario de Fauna y Flora Isla Malpelo, Pacífico Colombiano. Abstract, p. 298. Décimo Congreso Latinoamericano de Ciencias del Mar (X-COLACMAR), San José, Costa Rica.

Bussing, W.A. \& M.I. López. 2005. Peces de la Isla del Coco y peces arrecifales de la costa Pacífica de América Central meridional/Fishes of Cocos Island and Reef Fishes of the Pacific Coast of Lower Central America. Rev. Biol. Trop. 53 (Suppl. 2): 192 p.

Bussing, W.A. \& M.I. López. 2009. Text: 453-458, Species list, CD: 412-473. In: I.S. Wehrtmann and J. Cortés (Eds.). Marine Biodiversity of Costa Rica, Central America. Springer, Berlin.

Compagno, L. 1984. Sharks of the World. An Annotated and Illustrated Catalogues of Shark Species Known Date. Part 1. Hexanchiformes to Lamniformes. FAO Species Ccatalogue. FAO Fish. Synop. 4: 249 p.

Compagno L. 2001. Species Catalogue the Shark of the World. An Annotated and Illustrated Catalogue of Shark Species Known to Date. FAO Species Catalogue for Fishery Purposes 1: 269 p.

Cortés, J. 2008. Historia de la investigación marina de la Isla del Coco, Costa Rica. Rev. Biol. Trop. 56 (Suppl. 2): $1-18$.

Cortés, J. \& S. Blum. 2008. Life to $450 \mathrm{~m}$ depth at Isla del Coco, Costa Rica. Rev. Biol. Trop. 56 (Suppl. 2): 189-206. 
Dawson, C.L. \& R.M. Starr. 2009. Movements of subadult prickly sharks, Echinorhinus cookei, in the Monterey Canyon. Mar. Ecol. Prog. Ser. 386: 153-262.

Feitoza, B.M., L.A. Rocha, O.J. Luiz,Jr, S.R Floeter \& J.L. Gasparini. 2003. Reef fishes of St. Paul's Rocks: new records and notes on biology and zoogeography. J. Ichthiol. Aquat. Biol. 7: 61-82.

Garrison G. 2005. Peces de la Isla del Coco/Isla del Coco Fishes, 2nd ed. Editorial INBio, Santo Domingo de Heredia, Costa Rica.

Lizano, O.G. 2001. Batimetría de la plataforma insular alrededor de la Isla del Coco, Costa Rica. Rev. Biol. Trop. 49 (Suppl. 2): 163-170.

Lizano, O.G. 2012. Lizano, O.G. 2012. Rasgos morfológicos alrededor de la Isla del Coco y de sus montes submarinos vecinos, Pacífico de Costa Rica. Rev. Biol. Trop. 60 (Supl. 3): 43-51.

Long, D.J., J.E. McCosker, S. Blum \& A. Klapfer. 2011. Tropical Eastern Pacific records of the Prickly Shark, Echinorhinus cookei (Chondrichthyes: Echinorhinidae). Pac. Sci. 65: 433-440

López-Garro, A., I. Zanella, G. Golfín-Duarte \& M. PérezMontero. 2012. First record of the blacktip reef shark Carcharhinus melanopterus (Carcharhiniformes: Carcharhinidae) from the Eastern Tropical Pacific. Rev. Biol. Trop. 60 (Suppl. 3): 275-278.

McCosker, J.E. \& R.H. Rosenblatt. 2010. The fishes of the Galápagos Archipelago: an update. Proc. California Acad. Sci. $4^{\text {th }}$ Ser, 61 (Suppl. II): 167-195.

McEachran, J.D. \& G. Notarbartolo di Sciara. 1995. Peces Batoideos. p. 745-792. In: W. Fischer, F. Krupp, F. Schneider, C. Sommer, K.E. Carpenter, \& V.H. Niem (Eds.). Guía FAO para la identificación de especies para los fines de la pesca. Pacifico Centro-Oriental. Vol. 2. Vertebrados. Parte 1. FAO, Rome.

Mejía-Falla, P.A. \& A.F. Navia. 2011. Relationship between body size and geographic range size of elasmobranchs from the Tropical Eastern Pacific: An initial approximation for their conservation. Cienc. Mar. 37: 305-321.

Rojas, J.R., C.I. Fuentes \& N.R. Hernández. 2006. Echinorhinus cookei Pietschmann, 1928 (Chondrichthyes: Squaliformes, Echinorhinidae), primer registro en aguas de El Salvador, Pacífico oriental tropical. Rev. Biol. Mar. Oceanogr. 41: 117-119.
Rojas, W. \& G.E. Alvarado. 2012. Geología y contexto geotectónico de la Isla del Coco y la zona marítima frente al Pacífico central de Costa Rica. Rev. Biol. Trop. 60 (Suppl. 3): 15-32.

Sánchez, A.C. 1997. Listado taxonómico de las especies marinas identificadas en los océanos Pacífico y Atlántico (Caribe) de Nicaragua. Ministerio de Economía y Desarrollo, MEDE PESCA, Managua, Nicaragua. $28 \mathrm{p}$.

Sibaja-Cordero, J.A. 2008. Tendencias espacio-temporales de los avistamientos de fauna marina en los buceos turísticos (Isla del Coco, Costa Rica). Rev. Biol. Trop. 56 (Suppl. 2): 113-132.

Starr, R.M., K. Green \& E. Sala. 2012. Deep-water fish assemblages at Isla del Coco National Park and Las Gemelas Seamount, Costa Rica. Rev. Biol. Trop. 60 (Suppl. 3): 347-362.

Whitney, N.M. \& P.J. Motta, 2008. Cleaner host posing behavior of whitetip reef sharks (Triaenodon obesus) in a swarm of hyperiid amphipods. Coral Reefs (Reef Site) 27: 363 .

Whitney, N.M., H.L. Pratt \& J.C. Carrier. 2004. Group courtship, mating behaviour and siphon sac function in the whitetip reef shark, Triaenodon obesus. Anim. Behav. 68: 1435-1442.

Zanella, I., A. López-Garro, G. Golfín-Duarte \& J. C. Sáenz. 2012. Biología del tiburón punta blanca de arrecife, Triaenodon obesus (Carcharhiniformes: Carcharhinidae), en Bahía Chatham, Parque Nacional Isla del Coco, Costa Rica. Rev. Biol. Trop. 60 (Suppl. 3): 339-346.

\section{Internet references}

Froese, R. \& D. Pauly (Eds.). 2012. Fishbase. World Wide Web Electronic Publication. www.fishbase.org, Version (08/2012). Downloaded: May, 2012.

IUCN. 2012. The IUCN Red List of Threatened Species. Version 2011.2. <http://www.iucnredlist.org >. Downloaded: May 2012

Robertson, D.R. \& G.R. Allen. 2008. Peces Costeros del Pacífico Oriental Tropical: Sistema de Información en línea. Versión 1.0. Instituto Smithsonian de Investigaciones Tropicales, Balboa, República de Panamá. www.neotropicalfishes.org/ Donwloaded: January 2012. 


\section{Triaenodon obesus (Rüppell 1837). \\ White tip reef shark / Tiburón punta blanca de arrecifes, tiburón cazón coralero.}

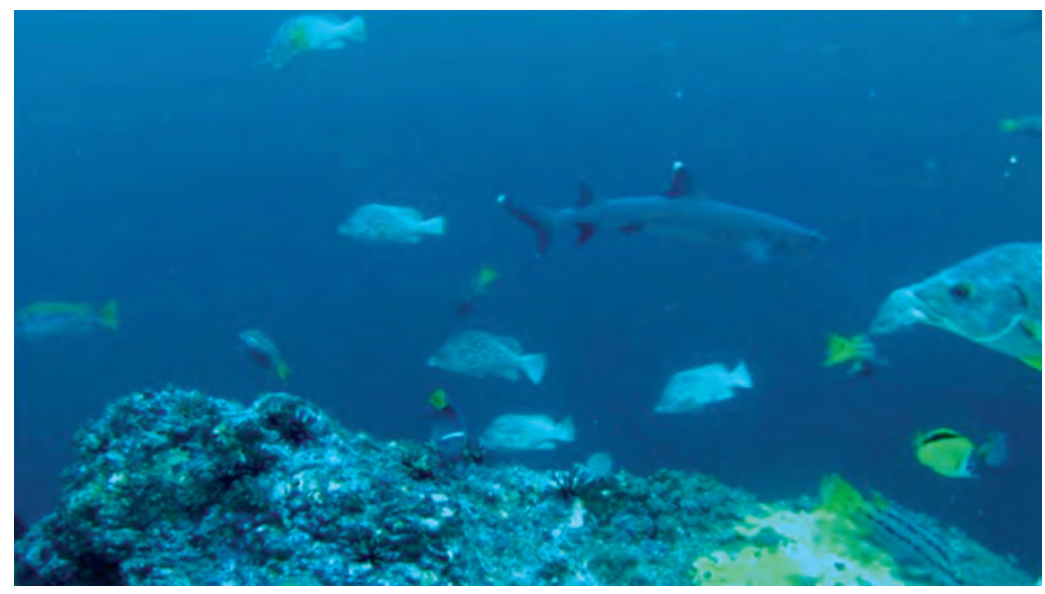

Fig. 2. Triaenodon obesus at Everest, $45 \mathrm{~m}, 17$ October 2009.

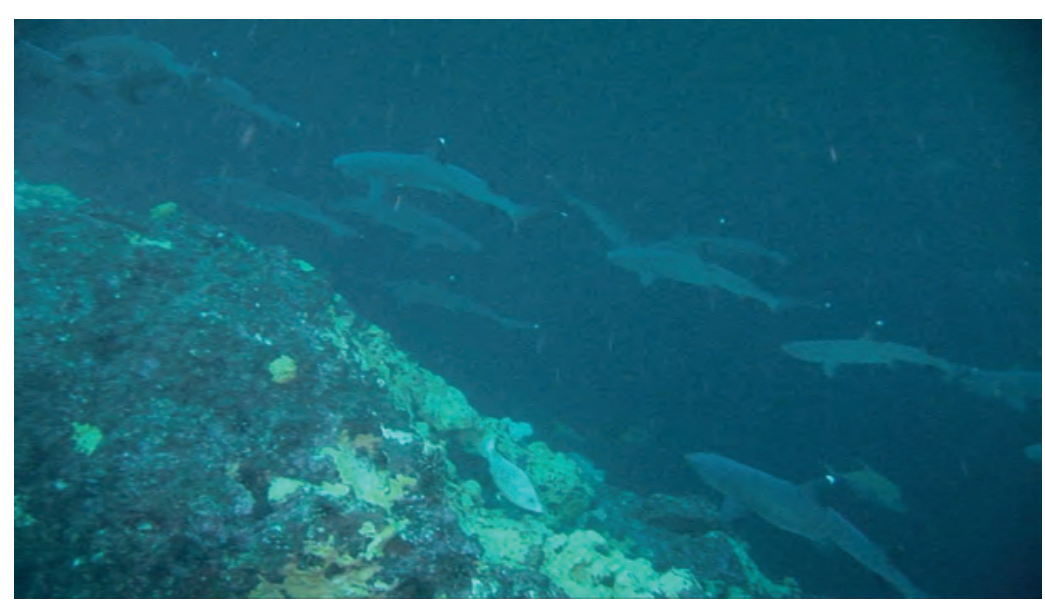

Fig. 3. School of white tip reef sharks at Everest, 50m, in the afternoon of 30 April 2009.

Description: Tips of first dorsal fin and upper caudal lobe white (Bussing \& López 2005). Brownish grey, with a few scattered grey spots on body, and a yellow cast ventrally (Robertson \& Allen 2008). Short snout and small smooth-edged teeth with strong cusplets in both jaws. Size: up to $213 \mathrm{~cm}$. Depth: 1-330m, usually 8-40m (Compagno 1984).

Worldwide Distribution: Tropical Indo-Pacific to Eastern Pacific; in the Eastern Tropical Pacific, from Nicaragua to Colombia (Garrison 2005), including all oceanic islands except Clipperton (Robertson \& Allen 2008).

Observations at Isla del Coco (DeEpSeE): Commonly observed between 80-301m, at Everest (80m) and The Wall 0475 (301m) during the afternoon. White tip reef sharks have been observed in deep waters year round mostly in the afternoons. Previous Reports: This is the most abundant species in the shallow waters of Isla del Coco (Garrison 2005). This is one of the two species that register more sightings per dive in the shallow waters of Isla del Coco (Sibaja-Cordero 2008). White tip shark prefer certain areas of the bays and apparently do not travel far from them (Zanella et al. 2012). This species has groups courtship and its mating behaviour has been reported in Isla del Coco (Whitney et al. 2004). Whitney and Motta (2008) described the interaction between these sharks and swarms of amphipods, at Manuelita, probably related with a cleaning process.

Comments: In the Eastern Tropical Pacific, reported between 2 and 300m, in an area of approximately 517,482km² (MejiaFalla \& Navia 2011). Classified as Near Threatened in the IUCN Red List. This means is not in danger of extinction, since it has relatively large and stable populations, as is the case in Isla del Coco National Park. 


\section{Sphyrna lewini (Griffith \& Smith, 1834). Scalloped hammerhead shark / Tiburón martillo, cornuda común.}

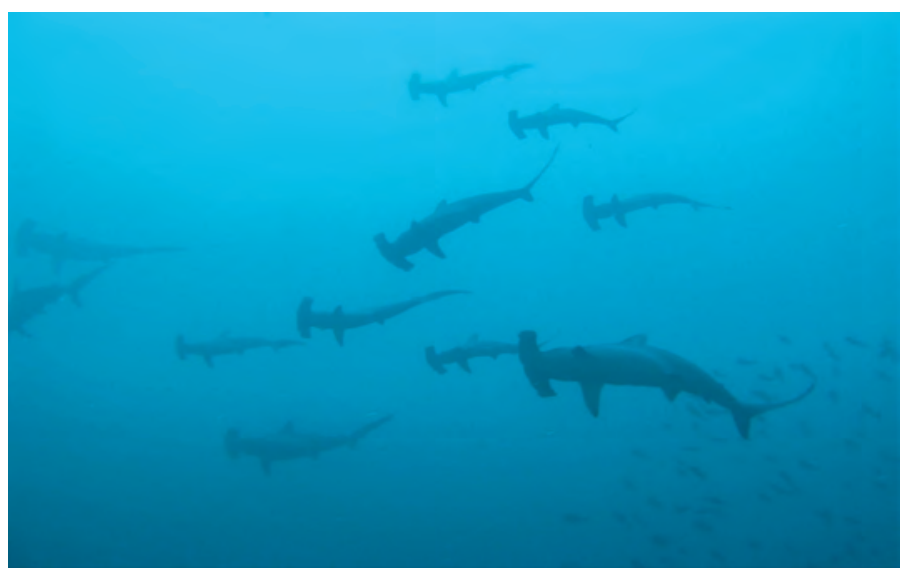

Fig. 4. Sphyrna lewini observed at Everest, 70m, 4 April 2007.

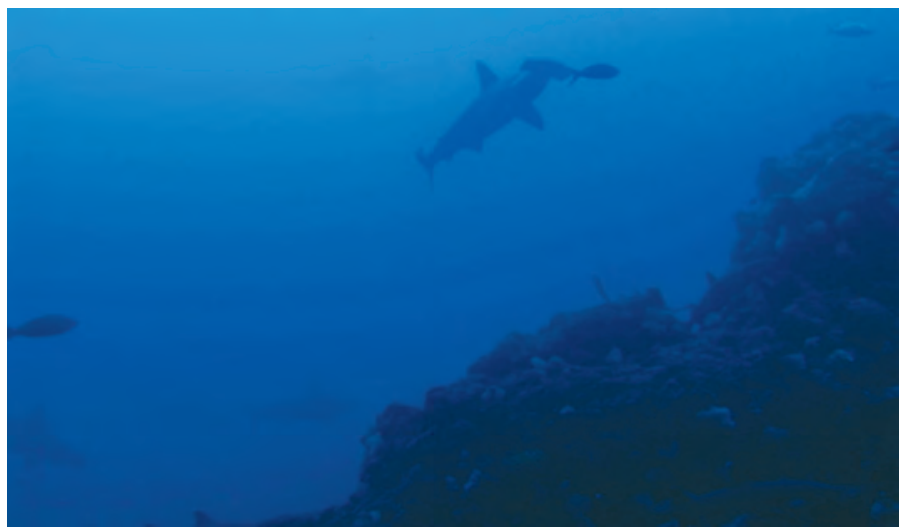

Fig. 5. Sphyrna lewini at Everest, 50m, 30 November 2009.

DESCRIPTION: Large hammerhead, with a head widened laterally; anterior head margin with 4 lobes and indented at midpoint (Bussing \& López 2005). Brownish gray along the dorsal surface, white ventrally (Robertson \& Allen 2008) and with blacktipped pectoral fins. First dorsal fin with origin over pectoral fin. Size: Reaches 430cm (Compagno 1984). Depth: 0-1000m (Besudo et al. 2011).

Worldwide Distribution: Circumtropical (Garrison 2005). From California to northern Peru, plus all oceanic islands of the Eastern Tropical Pacific. Also found in all warm temperate seas (Robertson \& Allen 2008).

Observations at Isla del Coco (DeEPSEE): At a depth range of 60 to 303m, mainly at Everest (60-90m) and Manuelita (45$60 \mathrm{~m})$, mornings and afternoons, year-round, and at most dive sites. At The Wall $0475(303 \mathrm{~m})$ during the morning. Second most observed elasmobranch in deepwaters.

Previous Reports: In shallow waters mainly at Roca Sucia and Bajo Alcyone (Sibaja-Cordero 2008), but also at Dos Amigos Grande, Manuelita y Roca Aleta de Tiburón, typically below the thermoclyne, at 50m (Garrison 2005). Observations in shallow water are scarce when water temperature exceeds normal sea surface temperature (Sibaja-Cordero 2008). Bessudo et al. (2011a) have reported scalloped hammerhead shark movements between Eastern Tropical Pacific islands, from Malpelo to Isla del Coco (in the south) and around the dorsal ridge of Malpelo. Reported by Starr et al. (2012) from waters deeper than $50 \mathrm{~m}$.

Comments: Sharks tagged in Malpelo and Isla del Coco were detected also in the Galapagos Islands, which demonstrates the broad movements in the Eastern Tropical Pacific, and urges multinational conservation efforts (Bessudo et al. 2011b). Classified as Endangered in the IUCN Red List. 


\section{Odontaspis ferox (Risso, 1810). \\ Smalltooth sand tiger shark / Tiburón solrayo.}

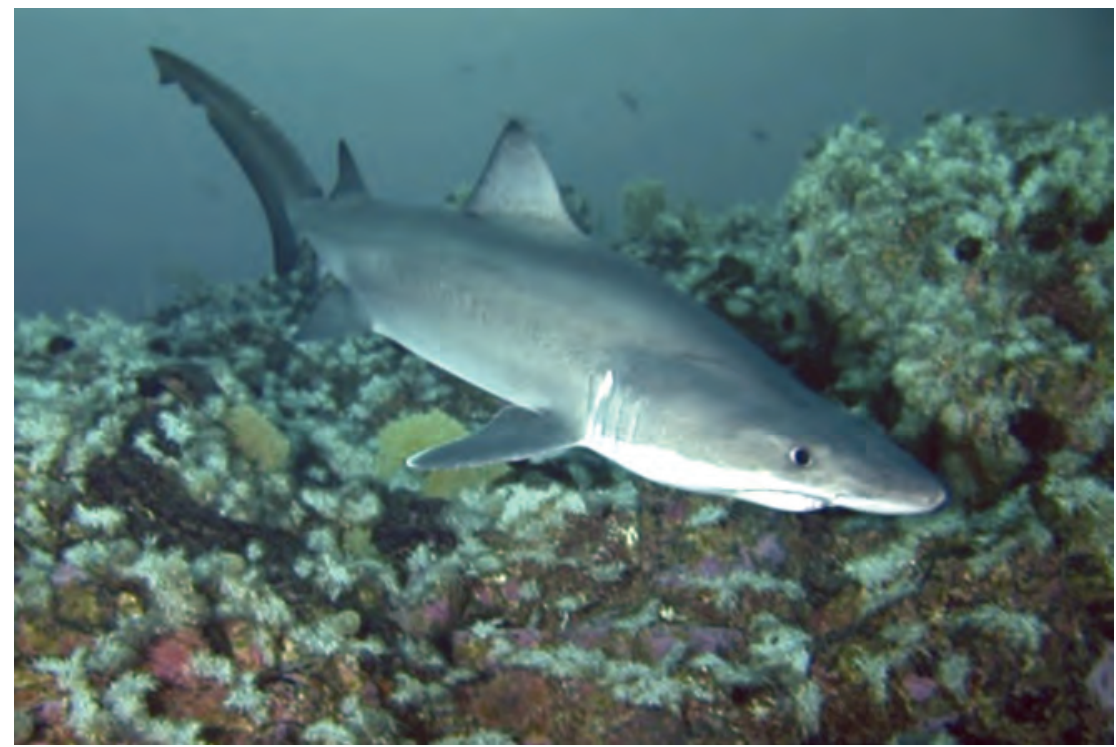

Fig. 6. Odontaspis ferox observed at The Arc, 95m, 2 January 2008.
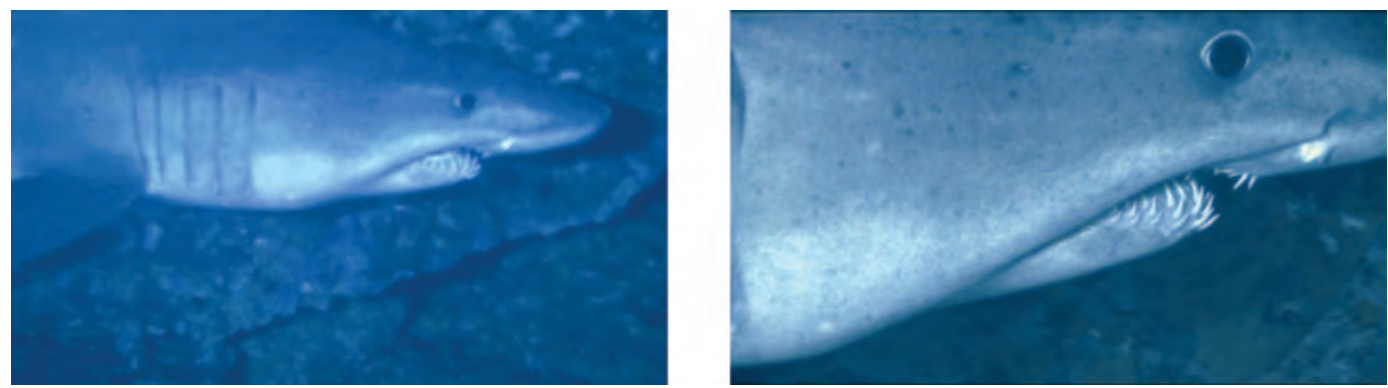

Fig. 7. Odontaspis ferox at Everest, 85m, 21 September 2007.

DESCRIPTION: Robust body, head with long conical snout; eyes moderately large, without nictitating membranes; gray on back, light gray below; sometimes with reddish spots on the body (Compagno 1984), young with black tips on dorsal fins. Size: up to $410 \mathrm{~cm}$ (Robertson \& Allen 2008). Depth: 10-530m in the Eastern Pacific (Mejía-Falla \& Navía 2011).

Worldwide Distribution: Circumglobal, predominantly in subtropical waters; Eastern Pacific from southern California to Malpelo (Robertson \& Allen 2008).

Observations at Isla del Coco (DEEPSEE): Observed at a depth range of $82-316 \mathrm{~m}$; at Everest $(82-85 \mathrm{~m})$, mornings and afternoons; at The Arch (90-95m) in the morning hours, and at The Wall 0475 (316m) in the afternoons. Not commonly observed.

Previous Reports: Cortés and Blum (2008) first reported the occurrence of this species in Isla del Coco National Park, at The Arch; a group of five, females and males.

Comments: The first observations in their natural habitat occurred in the eastern Pacific, in Isla Malpelo, with movements that seem related to the thermocline and a preference for cold waters between $18^{\circ} \mathrm{C}$ and $21^{\circ} \mathrm{C}$ (Bessudo \& Caballero 2003). Classified as Vulnerable in the IUCN Red List. 
Echinorhinus cookei Pietschmann, 1928.

Prickly shark / Tiburón negro espinoso.

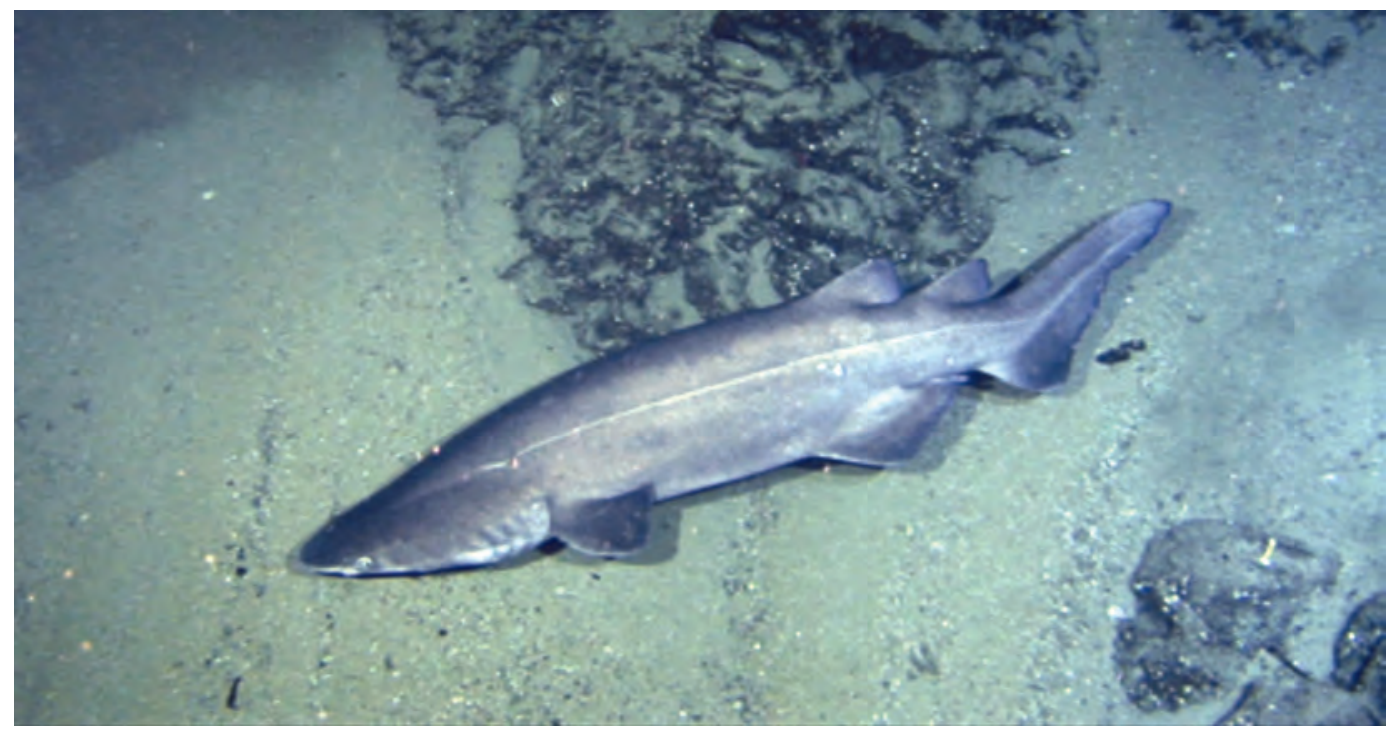

Fig. 8. Echinorhinus cookei at The Wall 0475, 312m, 27 June 2007.

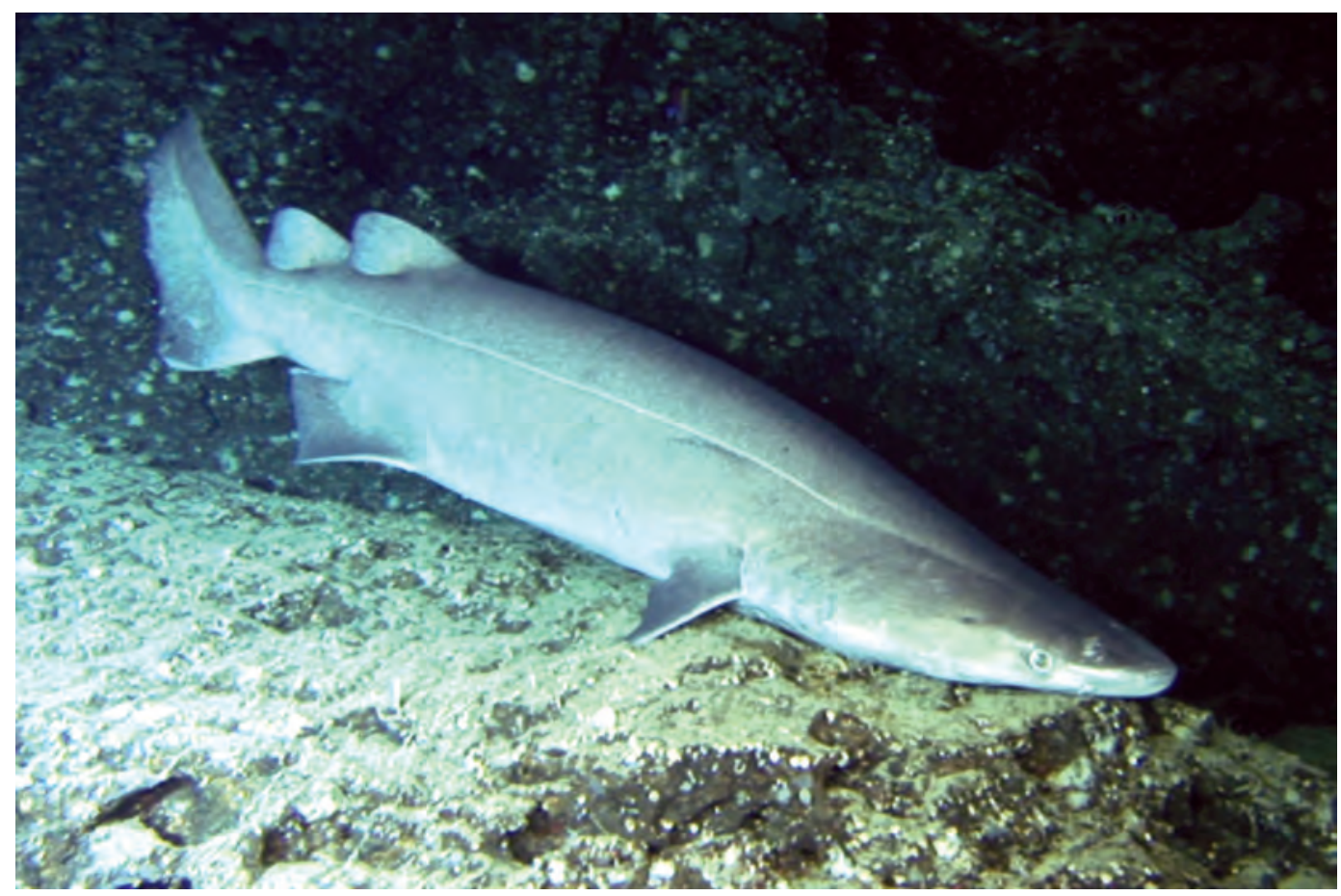

Fig. 9. Echinorhinus cookei at The Wall 0475, 312m, 27 June 2007. 


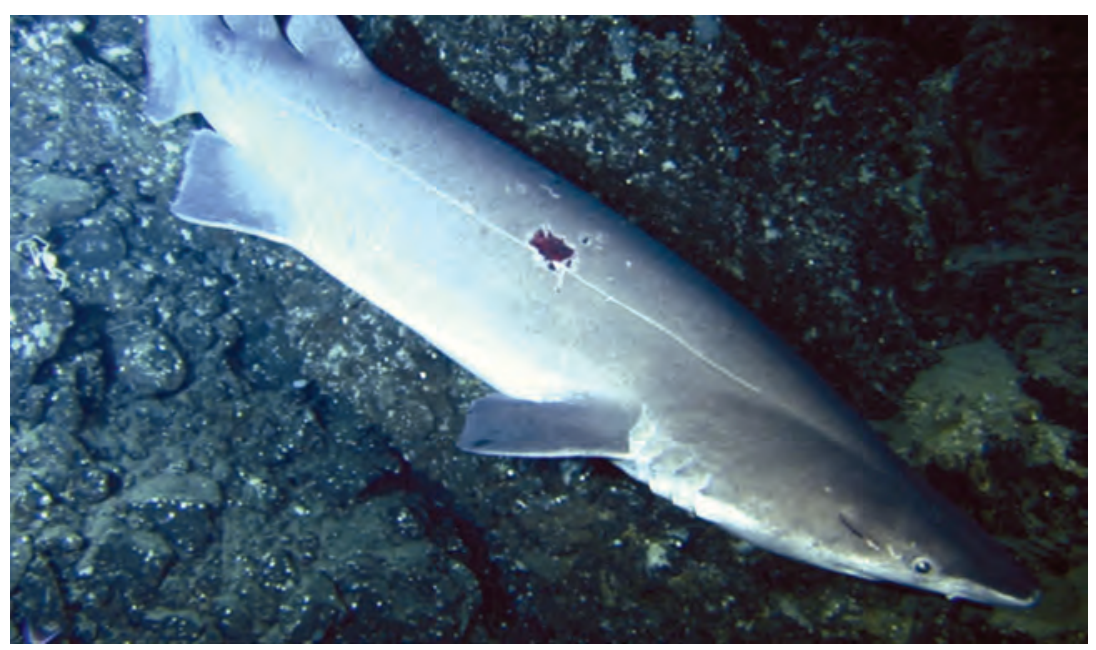

Fig. 10. Echinorhinus cookei at The Wall 0475, 313m, 17 May 2007.

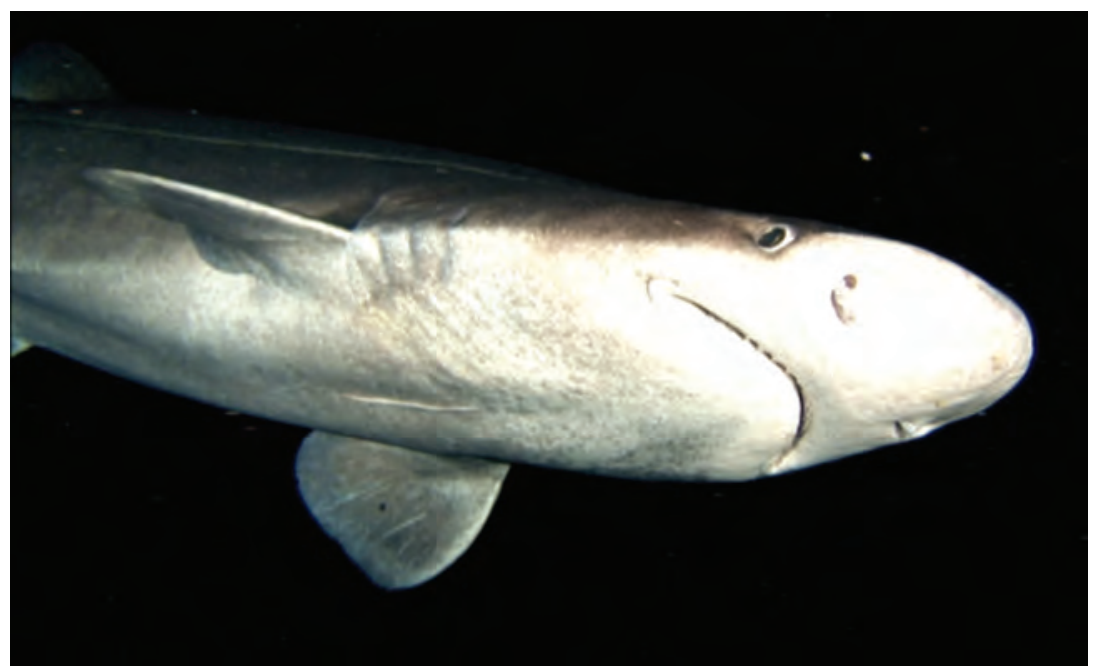

Fig. 11. Echinorhinus cookei at The Wall 0475, 312m, 27 June 2007.

DESCRIPTION: Large sharks with robust bodies, depressed head and small dorsal fins. Grey-white, white around snout and mouth. Size: 400cm (Robertson \& Allen 2008). Compagno (1984) reported this species from 11 to at least 424m; additional captures have extended the range up to $650 \mathrm{~m}$ and possibly around $1000 \mathrm{~m}$ (Dawson \& Starr 2009).

Worldwide Distribution: Subtropical to temperate Pacific (Robertson \& Allen 2008). Underwater observations from Galápagos Islands, Isla del Coco National Park and northern Peru confirm its continuous occurrence in the Tropical Eastern Pacific (Long et al. 2011). In the Eastern Pacific, from Oregon to Chile, and Malpelo, the Revillagigedos and Isla del Coco (Robertson \& Allen 2008). In Central America: El Salvador (Rojas et al. 2006), Nicaragua (Sánchez 1997) and off the coast of Costa Rica (Bussing \& López 2009).

Observations at Isla del Coco (DeepSee): At a depth range of 91-320m. At The Wall 0475 (300-320m) and Piedra Drop (301-311m), mornings and afternoons. At Everest (80m) and Piedra $165(160 \mathrm{~m})$ in the afternoon and at The Arch (91m) only in the mornings. Observed year-round and most commonly at Piedra Drop and The Wall 0475.

Previous RePorts: Underwater observations confirm the occurrence of this species in Isla del Coco National Park (Cortés \& Blum 2008, McCosker \& Rosenblatt 2010, Long et al. 2011).

Comments: E. cookei presents a wide range of depth in the eastern Pacific, despite the clear distinction of deep-water records that mostly correspond to low latitudes and the records of shallow waters that correspond mainly to high latitudes (Long et al. 2011). Classified as Near Threatened in the IUCN Red List, which means is not in danger of extinction. 


\section{Rhincodon typus Smith, 1828.}

\section{Whale shark / Tiburón Ballena.}

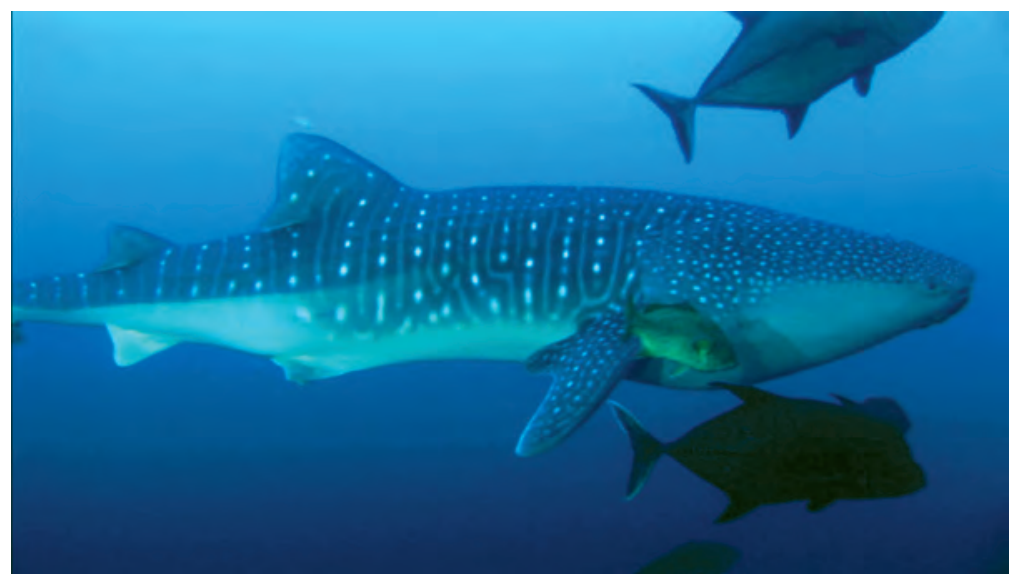

Fig. 12. Rhincodon typus at Everest, 80m, morning 16 July 2007.

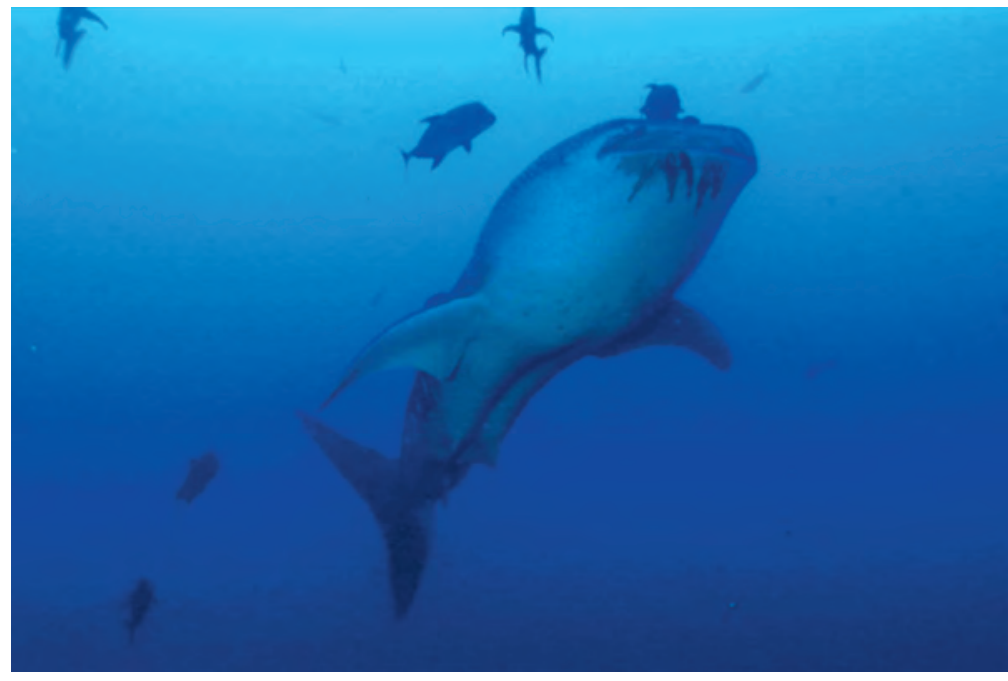

Fig. 13. Rhincodon typus at Everest, 80m, morning 16 July 2007.

Description: Rhincodon typus is the largest fish in the world (Bussing \& López 2005. With mouth wide, transverse; five massive gill slits and two dorsal fins (Robertson \& Allen 2008). Flat head and a large mouth with numerous teeth. A checkerboard pattern with spots of soft colors, grey horizontal and vertical stripes (Compagno 2001). Size $=$ up to $21 \mathrm{~m}$. Depth: 0-700m (Compagno 2001).

Worldwide Distribution: Circumglobal in tropical and subtropical seas (Garrison 2005, Robertson \& Allen 2008), including throughout the Tropical Eastern Pacific (Robertson \& Allen 2008).

Observations at Isla del Coco (DeEPSEE): Between 77 and 80m at Everest, morning and afternoon. Observed only a few times in 2007 and 2010.

Previous Reports: In shallow waters (Garrison 2005, Sibaja-Cordero 2008), Roca Sucia and Isla Manuelita (Garrison 2005). Comments: Observed only at Everest in deep waters and in shallow waters, primarily around Isla Manuelita. Is known about numerous reports in Cabo San Lucas, Acapulco and the Gulf of Mexico in the eastern Pacific, with preference to areas of upwelling and temperatures of $17^{\circ} \mathrm{C}$ or less, optimal sites for the production of their food (plankton) (Compagno 1984). Classified as Vulnerable in the IUCN Red List, which means it is a threatened species. 


\section{Taeniura meyeni Müller \& Henle, 1841. Marbled ray / Raya moteada.}

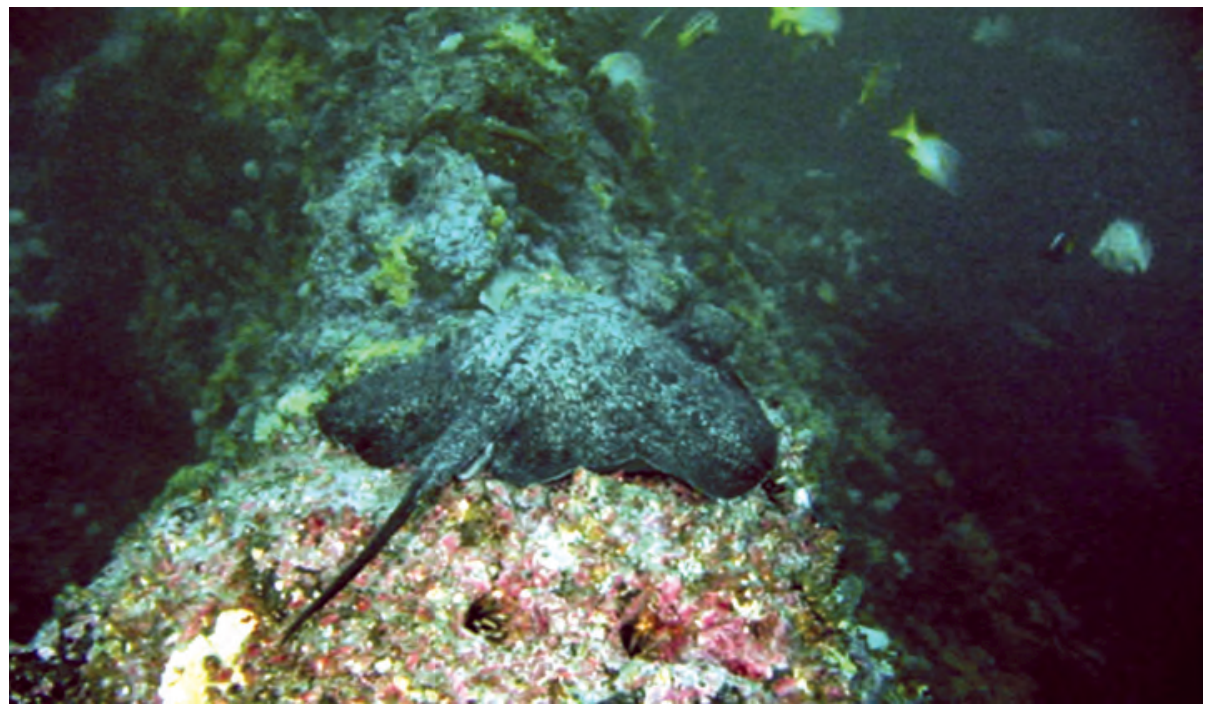

Fig. 14. Taeniura meyeni at Everest, 45m, 18 March 2009.

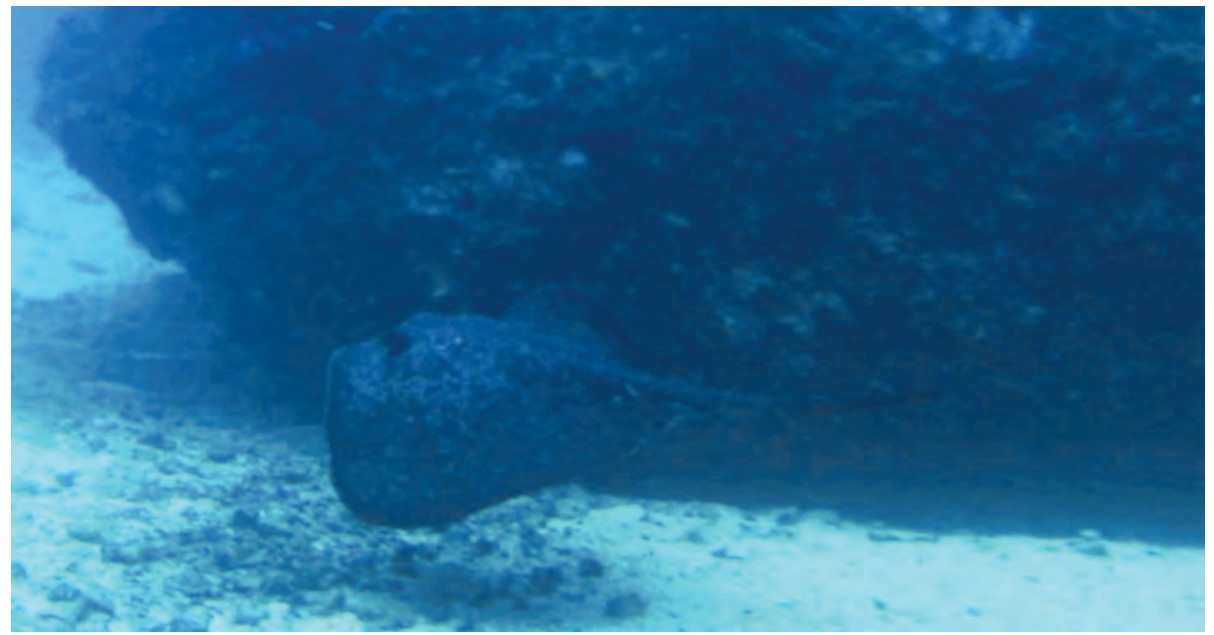

Fig. 15. Taeniura meyeni at Everest, 82m, 11 September 2009.

DesCriPtion: Disc wider than long, rhomboid; tail slightly longer than disc, tail fin with a small upper ridge on top and a deep fold. Greyish-blue on back with dark spots (Bussing \& López 2005). Size: 300cm long, 75cm wide. Depth: 5-500m (Robertson \& Allen 2008).

Worldwide Distribution: Indo-West Pacific Ocean, oceanic islands in the Tropical Eastern Pacific (Garrison 2005); resident in the Galápagos Islands and Isla del Coco (Robertson \& Allen 2008).

Observations at Isla del Coco (DeEpSeE): Everest, 45-90m, morning hours.

Previous Reports: Observed in shallow waters and up to 50m (Garrison 2005). Sibaja-Cordero (2008) considers that they may move to deeper waters in extreme warm weather conditions, i.e. El Niño years.

Comments: Observed only in morning hours.Although common in oceanic islands of eastern Pacific (Isla del Coco and Galapagos Islands), may also colonize the waters near the mainland of Central America (Froese \& Pauly 2012). Classified as Vulnerable in the IUCN Red List. Abundant in Isla del Coco National Park. 


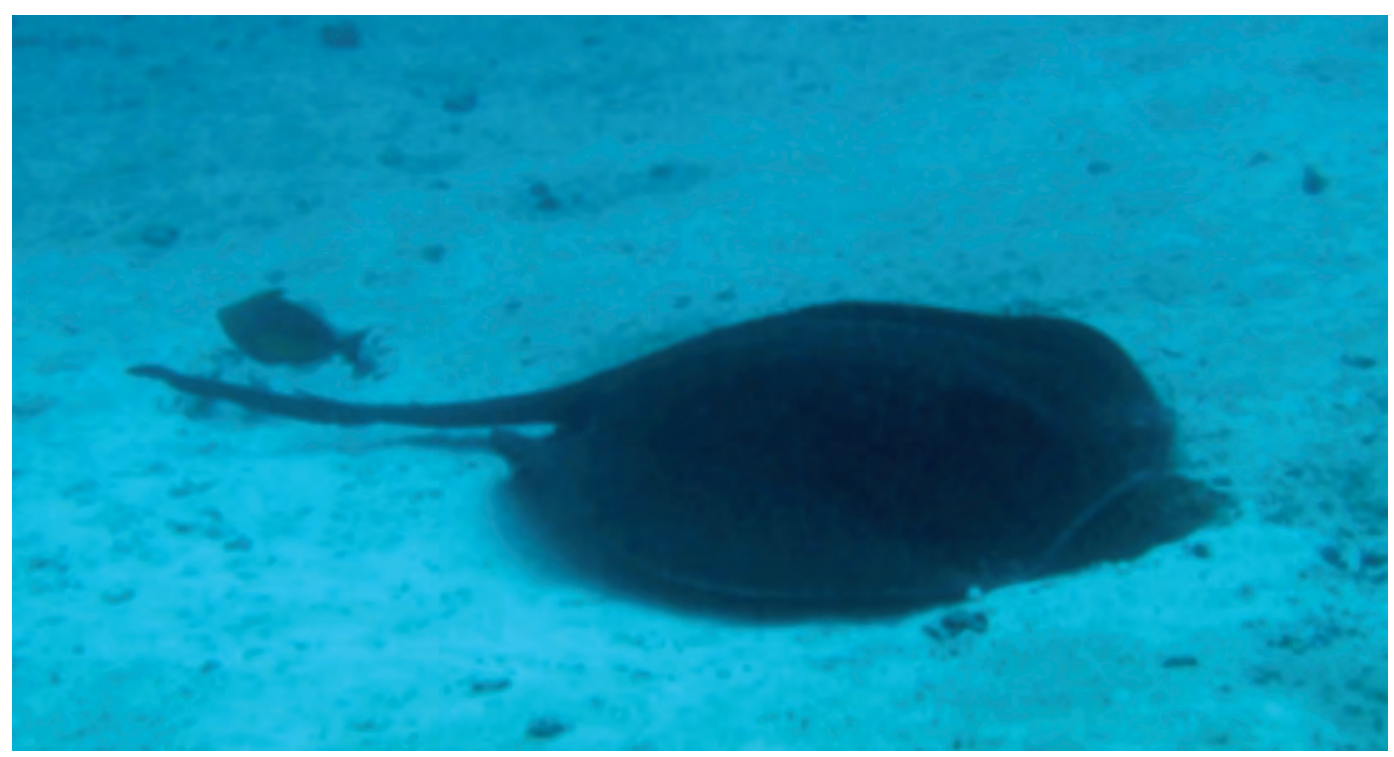

Fig. 16. Dasyatis sp. Everest, 60m, 13 January 2008, in the afternoon.

DESCRIPTION: Oval-shaped disc, broader than long; tail slightly longer than length of disc; tail fin absent but with dorsal and ventral folds, and a long line of thorns on base of tail. Lacks a characteristic colour pattern but typically brown or black. Maximum length: $180 \mathrm{~cm}$ (disc width $122 \mathrm{~cm}$ ). Depth: 0-70m (Robertson \& Allen 2008).

Worldwide Distribution: Southern California to Peru, the Revillagigedo and the Galápagos Islands (Robertson \& Allen 2008).

Observations at Isla del Coco (DEEPSEE): Everest, 60m, afternoon.

Previous Reports: There are no previous reports from Isla del Coco.

Comments: The taxonomy and biology of Dasyatis is poorly understood and it is possible that McCosker and Rosenblatt (2010) records are based on a new species of Dasyatis (J.E. McCosker pers. comm. 2012). Observed only in the afternoon. Classified in the IUCN Red List as Data Deficient, which means there is not enough knowledge to determine whether it is threatened or not. 


\section{Manta birostris (Walbaum, 1792). \\ Giant manta / Manta gigante.}

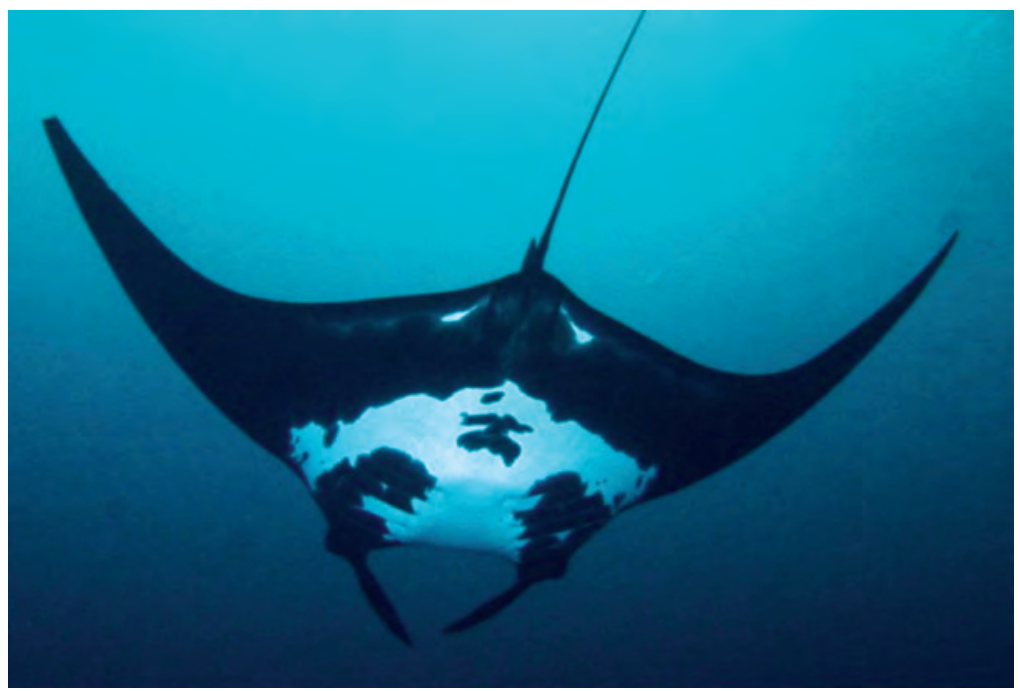

Fig. 17. Manta birostris at Everest, 90m, 20 March 202009.

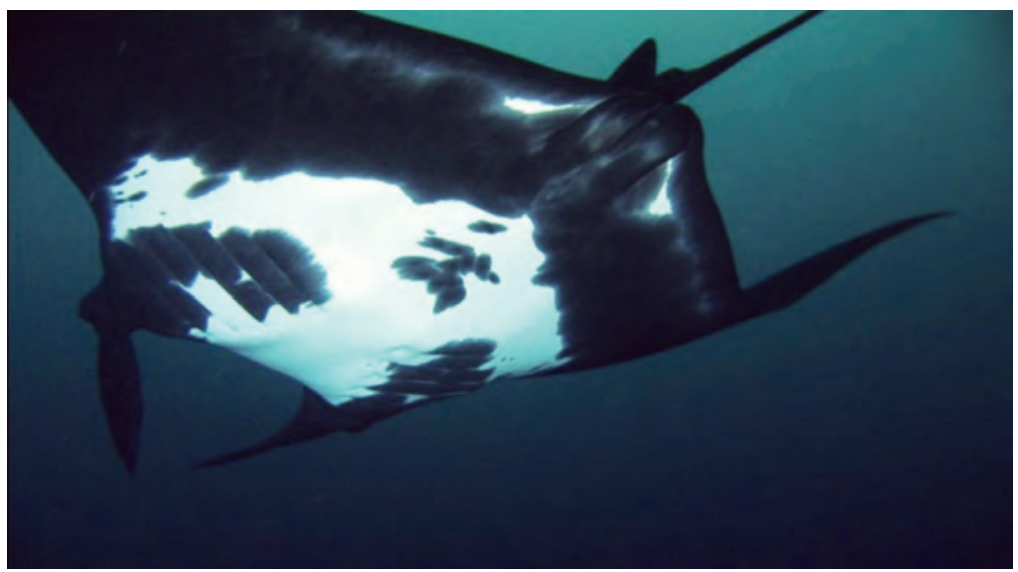

Fig. 18. Manta birostris at Everest, 90m, 20 March 202009

Description: Angular disc, at least twice as wide as long (Garrison 2005). A very large species, mouth at front of head (Bussing \& López 2005). Head relatively wide, with a pair of paddle-like extensions; large triangular fins; whip-like tail, without a spine. Grey to black above with white patches on shoulders; white on underside. Size: width of disc, $8 \mathrm{~m}$. Depth: 0-30m (Mejía-Falla \& Navia 2011)).

Worldwide Distribution: Circumtropical (Garrison 2005, McCosker \& Rosenblatt 2010). In the Eastern Pacific, from the Gulf of California to Ecuador (Garrison 2005, Robertson \& Allen 2008).

Observations at Isla del Coco (DEEPSEE): Everest, 90m, morning. Rarely observed.

Previous Reports: Shallow waters at Chatham Bay, Roca Sucia, Punta Mantas, Manuelita, Roca Aleta de Tiburón, Roca Sumergida and Punta Ulloa (Garrison 2005). Low densities were reported in shallow waters during El Niño years 1991-1992 and 1997-1998 (Sibaja-Cordero 2008).

Comments: In deep water they have only been observed at Everest. According to Mejía-Falla \& Navia (2011) in the eastern Pacific M. birostris extends approximately $1,432,316 \mathrm{~km}^{2}$. Classified as Vulnerable in the IUCN Red List due to fishing pressure; they get entangled in fishing lines and nets. 


\section{Mobula tarapacana (Philippi, 1892). Sicklefin devil ray / Manta cornuda, manta moruma.}

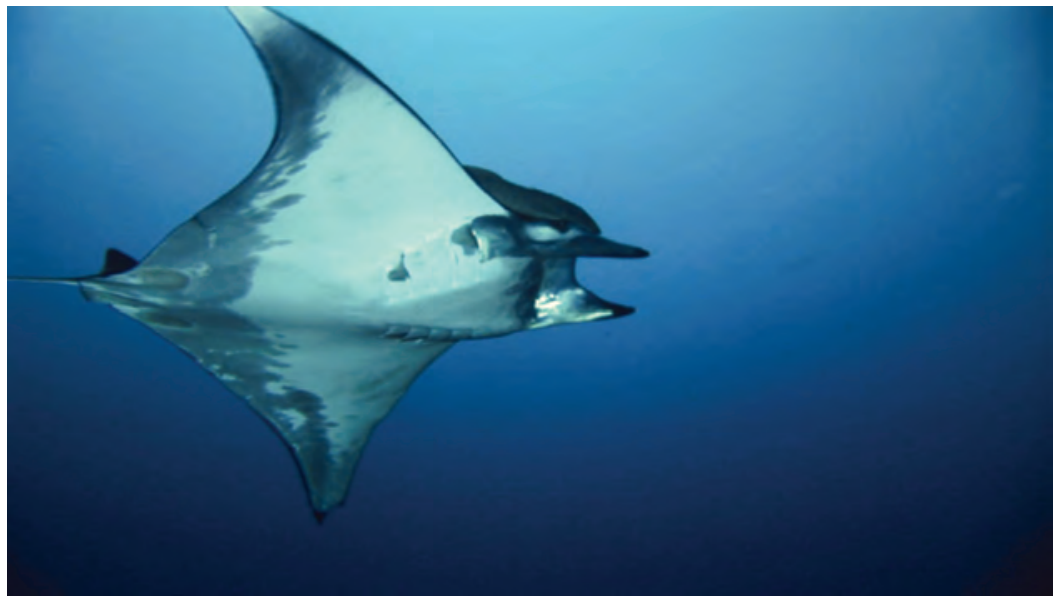

Fig. 19. Mobula tarapacana at Everest, 77m, 30 August 2007, in the morning.

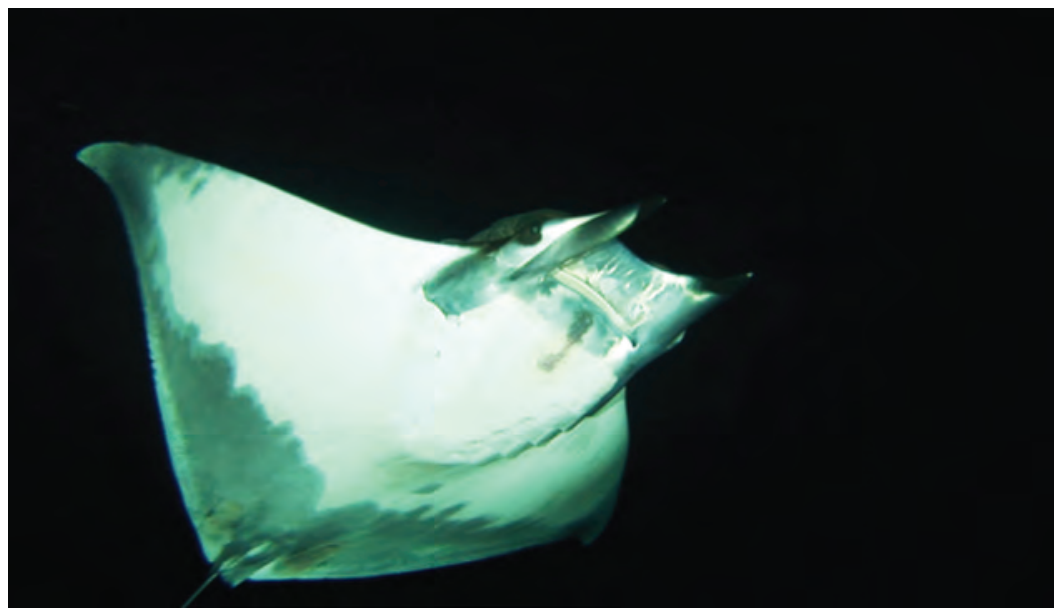

Fig. 20. Mobula tarapacana at Piedra 165, 220m, 1 July 2007.

DesCriPTION: Tail shorter than disc, whip-like; maximum disc width, 3m (Garrison 2005). Head relatively long, with short horns; large triangular fins strongly curved backwards; mouth on underside of head. Dorsal surface olive-green, underside white at front, grey posteriorly (Robertson \& Allen 2008). Size: up to 300cm (McEachran \& Nortarbartolo di Sciara 1995). Depth: up to $30 \mathrm{~m}$ (Feitoza et al. 2003).

Worldwide Distribution: Circumtropical (Garrison 2005, McCosker \& Rosenblatt 2010), in Indo-Pacific and Eastern Atlantic. In Eastern Pacific, from southern California to Ecuador (Garrison 2005).

Observations at Isla del Coco (DEEPSEE): Depth range 60-326m. At Kili 1 (220m) and Kili 2 (205-313m) in the afternoon; at Everest (60-90m), The Wall 0475 (280-326m) and Piedra 165 (204-230m), morning and afternoon. The most commonly observed elasmobranch; every year since 2007 (when records were started), year-round, and some years in high numbers, mainly at Piedra Drop and at The Wall 0475.

Previous Reports: According to Sibaja-Cordero (2008) this species was observed in shallow waters. He also reported low densities in 1991-1992 and 1997-1998, during El Niño years. Reported by Starr et al. (2012) from waters deeper than 50m. Comments: Depth range expanded to 326m, more than ten times the maximum depth stated by Feitoza et al. (2003). Classified in the IUCN Red List as Data Deficient, which means there is not enough knowledge to determine whether it is threatened or not. However this species may well be as threatened as the giant manta due to fishing pressure. 


\section{Aetobatus narinari (Euphrasen, 1790). Spotted eagle ray / Chucho pintado, raya águila.}

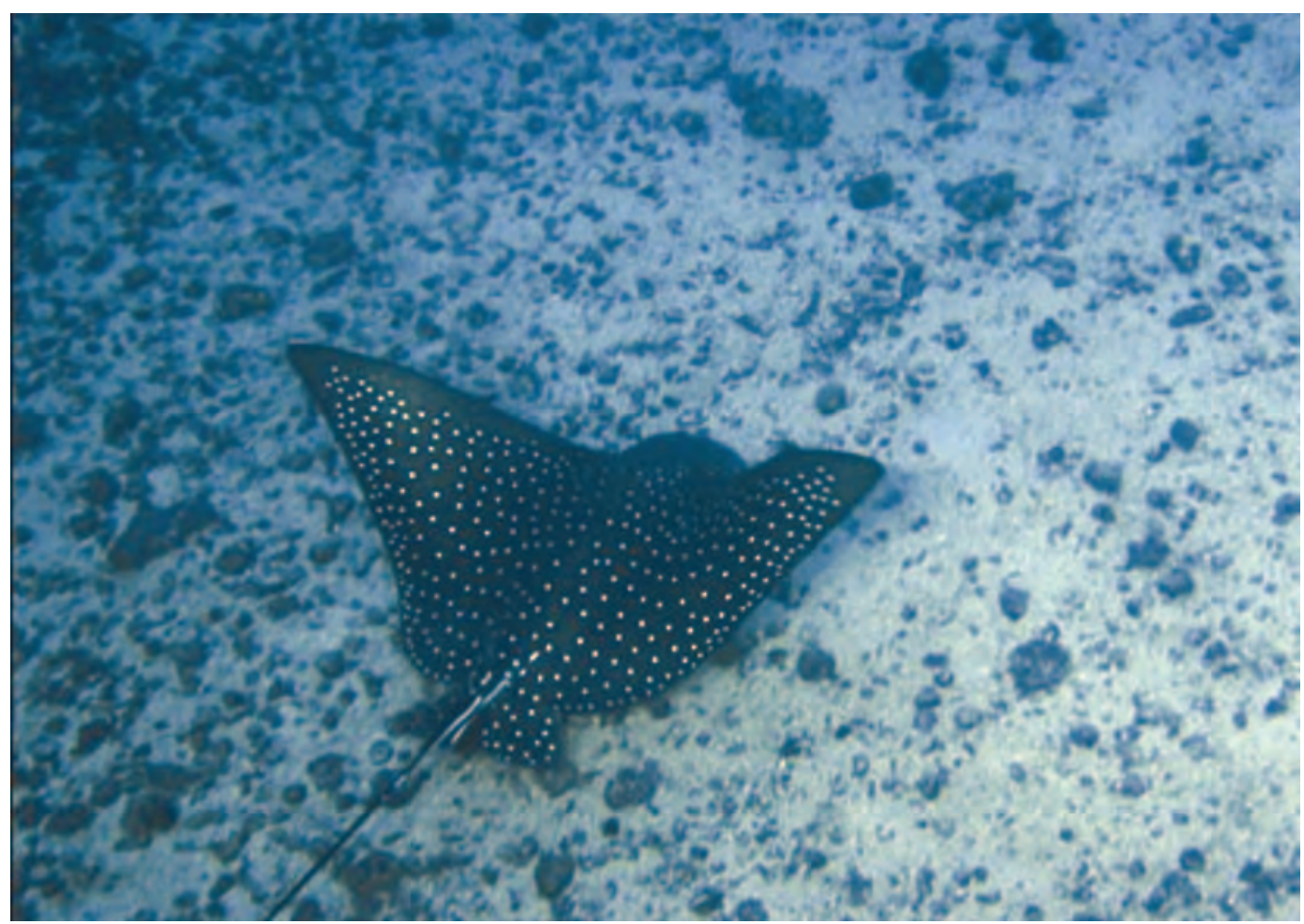

Fig. 21. Aetobatus narinari at Everest, 80m, 15 May 2007, morning.

DESCRIPTION: Black with numerous white spots; pointed snout; tail long and whip-like, with a venomous spine (Bussing \& López 2004). White below, disc angular, nearly twice as wide as long; no tail fin or fin folds (Robertson \& Allen 2008). Size: disc width to $250 \mathrm{~cm}$. Depth: 1-80m (Mejia-Falla \& Navia 2011).).

Worldwide Distribution: Circumglobal in tropical to warm temperate seas (Garrison 2005); Gulf of California to Ecuador, all the oceanic islands except Clipperton (Robertson \& Allen 2008).

Observations at Isla del Coco (DeEpSEE): Everest, 60-82m, morning and afternoon.

Previous Reports: Shallow waters at Roca Sucia, Dos Amigos Grande, inner side of Isla Manuelita, Isla Pájara, Roca Sumergida, Ulloa and Roca Viking (Cáscara) (Garrison 2005).

Comments: Mejia-Falla and Navia (2011) estimate that A. narinari extends over an area of about 1,472,360 km2 in the Eastern Tropical Pacific. Specifically in Isla del Coco, this species is in low densities in shallow waters. During the 19911992 El Niño its densities were particularly low; however the average for this species has slowly been increasing since 2001 (Sibaja-Cordero 2008). Classified as Near Threatened in the IUCN Red List. 


\section{Torpedo peruana Chirichigno, 1963. \\ Peruvian torpedo ray / Raya torpedo eléctrico, raya peruana.}

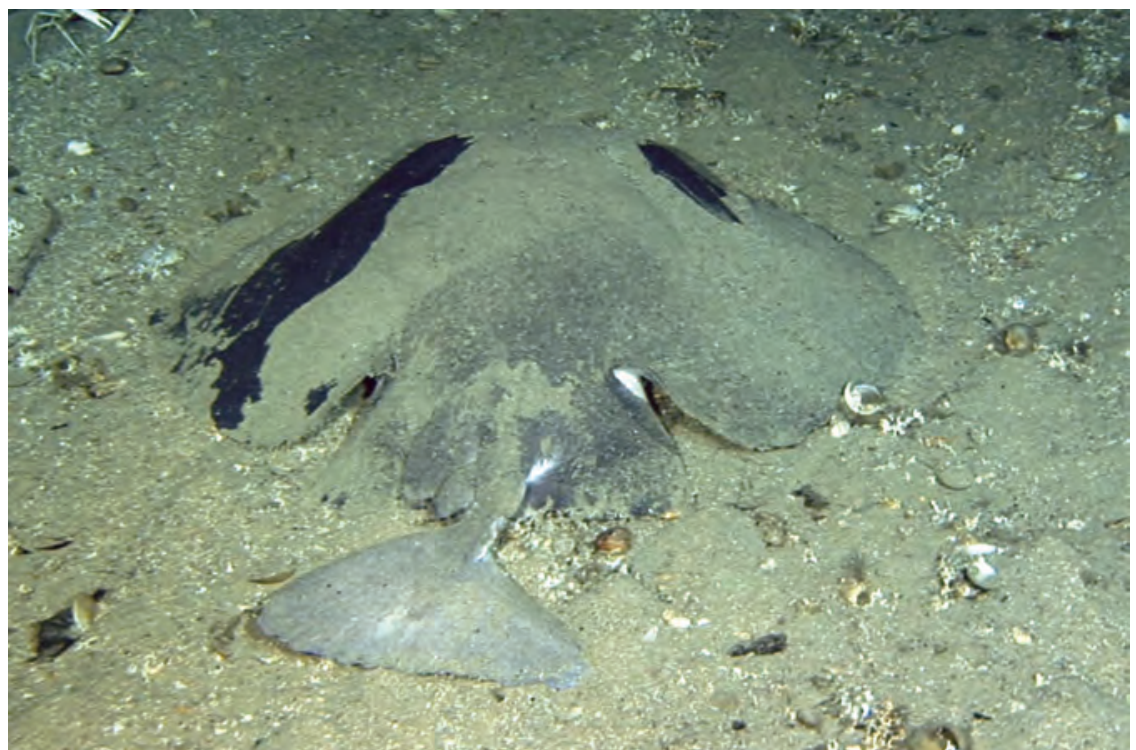

Fig. 22. Torpedo peruana at Kili 2, 313m, 14 July 2007.

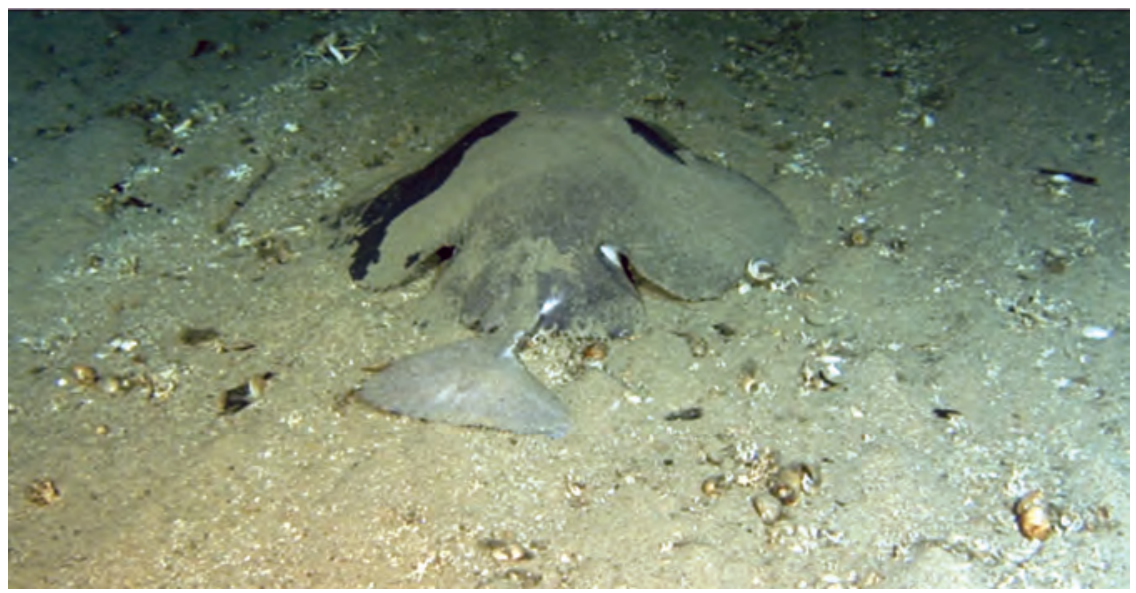

Fig. 23. Torpedo peruana at Kili 2, 313m, 14 July 2007.

DESCRIPTION: Pale brown upper surface, rear margins of fins with light coloured borders. Disc round, thick at front, thinner on and behind sides; a pair of large electric organs on head beside eyes; tail thick, shorter than disc. Tail fin large, rear margin without notch at its base. Size: reaches 50cm. Depth: 20-513m (McCosker \& Rosenblatt 2010).

Worldwide Distribution: Costa Rica to Peru, including Colombia (Angulo \& Acero 1999) and the Galápagos Islands (Robertson \& Allen 2008).

Observations at Isla del Coco (DeEPSEE): Kili 2, 313m, afternoon.

Comments: This is the first reported occurrence of Torpedo peruana in Isla del Coco National Park. Observed only at Kili 2. Records in the eastern Pacific range from 24 to 170m depth, extending in an area of approximately $42124 \mathrm{~km}^{2}$ (Mejía-Falla \& Navia 2011). Classified in the IUCN Red List as Data Deficient, which means the available information is not sufficient as to state whether this species is threatened or not. 
